\title{
BERBUSANA MUSLIMAH DAN HUBUNGANNYA DENGAN PERGAULAN BEBAS DI SMK PLUS TRIMITSA CIBINONG
}

\author{
Amelia; Dahlan Rabbanie; Salati Asmahasanah \\ Universitas Ibn Khaldun Bogor \\ oktavianiamelia097@gmail.com
}

\begin{abstract}
The study aims to determine the relationship of Muslim dress and promiscuity in students at Trimitsa Cibinong Vocational High School. The population is 41 students from the whole class 12, and the sample is 36 students. The method used is quantitative and questionnaire as an instrument, testing of research hypotheses is done using correlation analysis and regeneration, data analysis using Pearson Correlation statistical analysis. The results of this study indicate that the positive relationship between Muslim dress variables and promiscuity variables is calculated with Pearson Correlation, the correlation coefficient value obtained between these variables is 4,861. The coefficient of determination in this analysis obtained a value of 0,637 which means that promiscuity variables can be explained by Muslim dress variables. Based on the results of the study it can be said that Muslim dress (X) has a relationship with promiscuity (Y) of SMK Plus Trimitsa Cibinong female students.
\end{abstract}

Keywords: Muslim dress, dress criteria, promiscuity

\begin{abstract}
Abstrak
Penelitian bertujuan untuk mengetahui hubungan berbusana muslimah dan pergaulan bebas pada peserta didik di Sekolah Menengah Kejuruan Plus Trimitsa Cibinong. Populasi berjumlah 41 siswi dari keseluruhan kelas 12, dan yang dijadikan sampel berjumlah 36 siswi. Metode yang digunakan adalah kuantitatif dan kuesioner sebagai instrumen, pengujian hipotesis penelitian dilakukan dengan menggunakan analisis korelasi dan regreasi, analisis data menggunakan analisis statistik Pearson Correlation. Hasil penelitian ini menunjukan bahwa hubungan positif antara variabel berbusana muslimah dan variabel pergaulan bebas dihitung dengan Pearson Correlation, nilai koefisien korelasi yang diperoleh antara variabel tersebut sebesar 4,861. Nilai koefision determinasi dalam analisis ini diperoleh nilai 0,637 yang berarti variabel pergaulan bebas bisa dijelaskan dari variabel berbusana muslimah. Berdasarkan hasil penelitian dapat dikatakan bahwa berbusana muslimah $(X)$ memiliki hubungan dengan pergaulan bebas (Y) siswi SMK Plus Trimitsa Cibinong.
\end{abstract}

Kata Kunci: berbusana muslimah, kriteria berbusana, pergaulan bebas 


\section{A. PENDAHULUAN}

Berbusana muslimah merupakan pakaian wanita Islam yang dapat menutupi aurat dan diwajibkan agama untuk menutupinya, berguna kemaslahatan dan kebaikan wanita itu sendiri.

Nashiruddin(2011:35)mengemukakan bahwa berbusana bertujuan untuk melindungi diri dari hal-hal buruk yang tidak diinginkan. Maka busana menjadi pencegahan awal untuk menjaga perempuan tetap mulia dan menjadi anggota masyarakat yang terhormat, sebagai pencegah pergaulan bebas yang terjadi. Selain itu, berbusana muslimah juga merupakan aturan berpakaian dalam syariat Islam yang harus ditaati oleh seluruh penganutnya.

Busana muslimah diartikan sebagai pakaian luar yang biasa dipakai seorang wanita untuk menghindari bahaya. Bahaya yang dimaksud adalah bahaya alamiah dan sosiologi.

Ridwan (2019:134) mengemukakan bahwa bahaya alamiah adalah bahaya yang berkaitan dengan kondisi alam, seperti cuaca panas dan dingin sehingga ketika wanita memakai busana muslimah akan terhindar dari bahaya penyakit yang diakibatkan oleh kondisi alam. Sedangkan bahaya sosiologi adalah bahaya yang disebabkan oleh pakaian yang dikenakan seorang muslimah bisa menimbulkan tindak kejahatan, apabila memakai busana yang tidak sesuai dengan Islam, maka hal tersebut dapat mengundang kejahatan.

Masa remaja dikatakan sebagai suatu masa yang berbahaya karena pada fase tersebut, seseorang meninggalkan fase kehidupan anak-anak untuk menuju ke fase selanjutnya, yaitu tahap pendewasaan (M. Dahlan R, 2020:55).

Masalah pergaulan bebas sering terdengar baik dilingkungan masyarakat maupun media massa. Secara umum pergaulan bebas terjadi dikalangan remaja. Akan tetapi, di zaman modern tingkat pergaulan bebas remaja tentu sangat mengkhawatirkan. Banyaknya remaja yang terjerumus kedalam pergaulan bebas bukan semata-mata tanpa sebab. Perbuatan tersebut terdapat berbagai faktor yang menggiring para remaja pada hal-hal negatif.

Pergaulan bebas dikalangan remaja berkembang dengan sangat pesat. Akan tetapi, lebih maju dalam pergaulan kearah yang negatif. Pergaulan bebas dikalangan remaja sudah banyak yang kelewat batas. Sikap dan tingkah laku remaja terbentuk disebabkan oleh pengaruh lingkungan luar (Nadhirah, 2017:40-41). Jika lingkungan luar sudah tidak baik, maka kepribadian juga dapat terpengaruh.

Rusaknya pergaulan bebas menyebabkan berbagai macam kerusakan moral. Pergaulan yang terjadi tidak sesuai dengan aturan-aturan agama dan jauh dari nilai kesopanan. Remaja melakukan pergaulan dengan seusianya sekedar untuk melampiaskan kesenangan semata tanpa memikirkan dampak dari pergaulan bebas.

Pergaulan bebas berbeda dengan remaja yang menggunakan busana muslimah di dalam pergaulan. Mereka memahami pemahaman agama lebih dan cenderung baik dibandingkan dengan remaja yang selalu mengutamakan pergaulan bebas. (Sudarsana, 2018:49-50) 
Seseorang yang menggunakan busana muslimah lebih membatasi pergaulannya terhadap lawan jenis. Hal tersebut terjadi dikalangan seorang muslimah. Sehingga bagi orang yang berbusana muslimah cenderung bergaul dengan sejenis, tetapi bagi orang yang tidak berbusana muslimah cenderung bergaul dengan lawan jenis. (Al-Utsmani, 2019:201)

Berdasarkan dari pernyataan tersebut maka permasalahan yang ingin dikaji adalah "Apakah terdapat hubungan antara berbusana muslimah dengan pergaulan bebas siswi Sekolah Menengah Kejuruan Plus Trimitsa Cibinong".

\section{B. METODE PENELITIAN}

Penelitian ini menggunakan pendekatan kuantitatif berupa studi kasus. Penelitian ini dilaksanakan di SMK Plus Trimitsa Cibinong. Waktu pelaksanaan selama 3 bulan, mulai dari bulan desember 2019 sampai dengan bulan februari 2020 .

Objek populasi dalam penelitian ini adalah siswi di kelas XII SMK Plus Trimitsa Cibinong yang berjumlah 41 orang dan sampel penelitian adalah 36 orang. Teknik pengambilan sampel yang digunakan adalah Probability Sampling yaitu Random Sampling.

Teknik pengumpulan data diperoleh dari instrumen yang digunakan sebagai pengumpuldata penelitianadalahkuesioner berjumlah15butirpernyataanuntukmasingmasing variabel berbusana muslimah dan pergaulan bebas. Dari kuesioner memiliki relibilitas (menggunakan Alpha Cronbach) 0,492 untuk variabel berbusana muslimah, 0,605 untuk variabel pergaulan bebas.
Data hasil penelitian dianalisis menggunakan uji analisis anova satu jalan dengan menggunakan bantuan program SPSS 22. Pengujian hipotesis dilakukan pada taraf signifikan 0.05 .

\section{HASIL DAN PEMBAHASAN}

Dalam pengujian data digunakan analisis statistik yang menyatakan ada hubungan antara berbusana muslimah dengan pergaulan bebas di Sekolah Menengah Kejuruan Plus Trimitsa Cibinong. Untuk itu digunakan analisi regresi dan korelasi dalam mencari kekuatan hubungan antar variabel bebas dan variabel terikat.

Berdasarkan hasil perhitungan analisis regresi diperoleh nilai konstanta $\mathrm{a}=4,861$ dan koefisien $b=0,637$ dan dapat dirumuskan persamaan regresi linier sederhana dengan persamaan $\mathrm{Y}=4,861 \times 0,637$.

\section{Tabel 1}

Regresi Linier Sederhana Berbusana Muslimah $(\mathrm{X})$ dengan Pergaulan Bebas $(\mathrm{Y})$
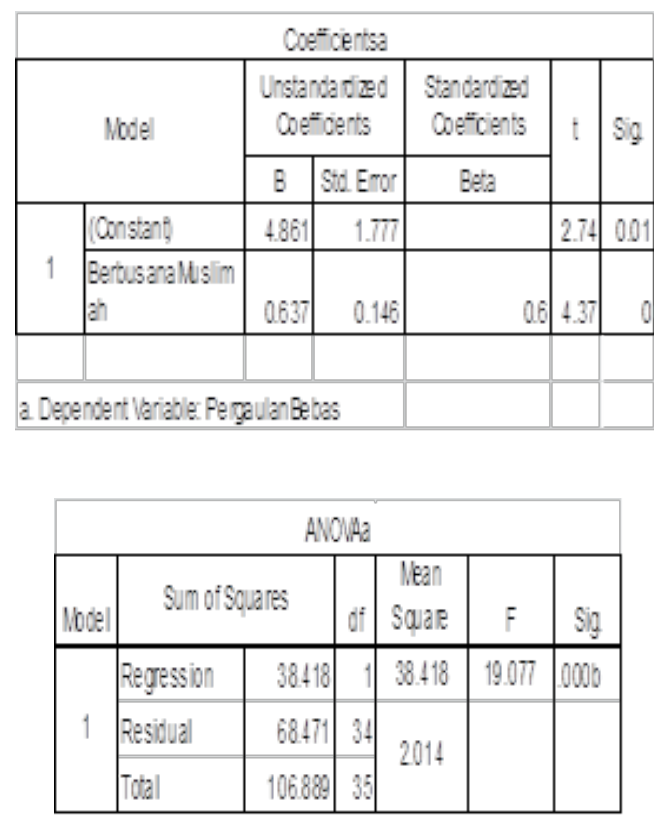
Berdasarkan hasil analisis di atas, uji signifikansi model regresi berdasarkan uji linearitas persamaan garis regresi diperoleh Fhitung (b/a) sebesar 1 dan p-value $=19,077$ dan $\mathrm{p}$-value $=0.000<0.05$, kesimpulan yang dapat diambil adalah H0 ditolak, sehingga dapat dinyatakan bahwa model persamaan regresi $\mathrm{Y}$ atas $\mathrm{X}$ adalah sangat signifikan.

Hasil pengujian tersebut menjadikan persamaan regresi yang dinyatakan dengan $Y=4,861 \times 0,637$ dapat digunakan untuk menyimpulkan hubungan antara berbusana muslimah dengan pergaulan bebas.

\begin{tabular}{|c|c|c|c|c|}
\hline \multicolumn{5}{|c|}{ Model Sum mary } \\
\hline Model & $R$ & $\begin{array}{c}R \\
\text { Square }\end{array}$ & $\begin{array}{c}\text { Adjusted R } \\
\text { Square }\end{array}$ & $\begin{array}{l}\text { Std. Error } \\
\text { of the } \\
\text { Estimate }\end{array}$ \\
\hline 1 & $.600 \mathrm{a}$ & 0.359 & 0.341 & 1.419 \\
\hline
\end{tabular}

Berdasarkan dari tabel tersebut berbusana muslimah sebesar 0,637 unit kearah positif dengan konstan 4.861.

Hipotesis bahwa "ada hubungan positif antara berbusana muslimah dengan pergaulan bebas", hubungan tersebut dihitungmenggunakan SPSS. Dari perhitungan, koefisien korelasi antara (rxy) sebesar 0,601 dan koefisien determinasi (R2) sebesar 0,359, karena ry2 berkonsultasi dengan tabel interpretasi dari nilai koefisien korelasi mungkin tingkat hubungan antara kedua variabel tersebut cukup kuat. Dapat disimpulkan bahwa ada hubungan positif yang signifikan antara berbusana muslimah dengan pergaulan bebas.
Dari hasil perhitungan ANOVA dan regresi linier diperoleh bahwa regresi berbusana muslimah sebesar 4,861 menunjukan bahwa setiap pergaulan bebas akan meningkatkan berbusana muslimah sebesar 19.077. Sedangkan standardized coeficients sebesar 0,601 menunjukkan angka korelasi, yang berarti hubungan antara berbusana muslimah dengan pergaulan bebas korelasi yang cukup kuat.

\section{SIMPULAN}

Hasil hipotesis seperti telah dikemukakan di atas dapat ditarik kesimpulan dari hasil penelitian di SMK Plus Trimitsa Cibinong. Terdapat hubungan yang cukup antara variabel berbusana muslimah dan variabel pergaulan bebas. Artinya semakin baik berbusana muslimah, akan membuat pergaulan bebas menjadi cukup baik dan kuat.

\section{E. IMPLIKASI DAN KETERBATASAN PENELITIAN}

1. Keterbatasan Penelitian

Pelaksanaan penelitian tentang berbusana muslimah dan hubungannya dengan pergaulan bebas di SMK Plus Trimitsa Cibinong sudah dilaksanakan sebaik mungkin dengan metode kuantitatif. Namun sebaik apapun metode yang digunakan, tidak tertutup kemungkinan adanya kekeliruan, kesalahan, kekurangan, dan keterbatasan, antara lain:

a. Jawaban-jawaban yang telah diberikan mungkin belum semuanya mencerminkan tentang kenyataan yang sebenarnya, sehingga masih patut dipertanyakan dan dicari tahu secara 
lebih lanjut.

b. Mengingat penelitian ini menyangkut masalah berbusana muslimah dan pergaulan bebas, maka dalam menjawab pernyataan kelihatannya responden sangat berhati-hati.

c. Penulis memiliki keterbatasan pengetahuan dan keterampilan teknis dalam melakukan penelitian sehingga hasil penelitian belum sempurna.

Dengan keterbatasan-keterbatasan tersebut tentunya penelitian-penelitian selanjutnya diharapkan dapat lebih berkembang dan mampu memperbaharui, hal-hal yang dianggap belum sempurna dan juga untuk menemukan suatu temuan yang dapat dipergunakan untuk meningkatkan dalam berbusana dengan pergaulan bebas.

\section{Implikasi}

Implikasi penelitian ini akan berdampak positif dan siginfikan dengan pergaulan bebas bilamana dalam berbusana muslimah ditingkatkan lagi lebih maksimal.

Upaya untuk meningkatkan berbusana muslimah terhadap pergaulan bebas dapat dilakukan melalui peningkatan dalam pemahaman seorang wanita dalam berbusana sebagai identitas seorang muslimah, serta mampu mengaplikasikan kriteria-kriteria berbusana muslimah sehingga dapat terhindar dari pergaulan bebas.

\section{DAFTAR PUSTAKA}

\section{Buku}

Muhammad, Abu. (2014). Wahai Ukhti Kenapa Engkau Tidak Berjilbab. Jakarta: Pustaka Ibnu 'Umar.

Nashiruddin, Muhammad. (2017) Kriteria Berbusana Muslimah. (Cet. 4). Jakarta: PT Pustaka Ima Asy-Syafi'i.

Hasan, Farid Nu'man. (2019). Fiqih Perempuan Kontemporer. (Cet. 4). Depok: Gema Insani.

Ath-Tharsyah, Adnan. (2011). Kiat Menjadi Muslimah Seutuhnya. (Cet. 1). (Jakarta: Senayan Publishing.

Al-Ashfahani, Ar-aghib. (2017). Kamus AlQur'an. Depok: Pustaka Khazanah Fawa'id.

Al-Utsmani, Syaikh Muhammad. (2019). Shahih Fiqih Wanita. Jakarta: Akbar Media.

Abidin, Ahmad Zainal. (2015). Untaian Hikmah Ulama Ahlussunnah. Yogyakarta: DIVA Press.

Muhammad, Al-Imam Jalaluddin. (2015). Tafsir Jalalain. (Cet. 2). Surabaya: PT elBA Fitrah Mandiri Sejahtera.

Jabir, Abu Bakar. (2011). Pedoman Hidup Muslim. (Cet. 5). Jakarta: PT Mitra Kerjaya Indonesia.

Khoiri, M. Alim. (2016). Fiqih Busana. Depok: KALIMEDIA.

Simpati, Sita. (2016). Wahai Muslimah Inilah Doamu. Jakarta: PT Mizan Pustaka.

Arikunto, Suharsimi. (2013). Prosedur Penelitian. (Cet. 15). Jakarta: PT Asdi Mahasatya.

Sugiyono. (2015). Metode Penelitian Pendidikan. (Cet. 11). (Bandung: 
Alfabeta.

Fikri, Miftahul. (2016). Cara Mudah Membuat Makalah, Skripsi dan Tesis. Bogor: ARABASTA MEDIA.

Sugiyono. (2018). Metode Penelitian Kuantitatif. (Bandung: Alfabeta. Sudarsono. (2015). Kenakalan Remaja. (Cet. 6). Jakarta: PT Asdi Mahasatya.

Suciati. (2018). Psikologi Komunikasi. (Cet. 3). Yogyakarta: Buku Litera.

\section{Jurnal}

R, M. Dahlan. (2018). Lingkungan Pendidikan IslamidanHubungannya dengan Minat Belajar Pendidikan Agama Islam. Jurnal Edukasi Islami. Vol 7 No 2.

Asmahasanah, Salati. (2019). Hubungan Pola Asuh Orang Tua dan Karakter Siswa dengan Penyalahgunaan Media Sosial. Jurnal Mitra Pendidikan. Vol 3 No 11.

Yazid, Tantri Puspita. (2017). Proses Persepsi Diri Mahasiswi Dalam Berbusana Muslimah. Jurnal An-nida'. Vol 41 No 2.

Murtopo, Bahrun Ali. (2017). Etika Berpakaian Dalam Islam. Jurnal Tajdid. Vol 1 No 2.

Ridwan, Yusup. (2019). Usaha-usaha Guru Pendidikan Agama Islam Dalam Mengembangkan Kesadaran Siswa Untuk Berbusana Muslimah. Jurnal Assalam. Vol II No 03.

Hastuti, Puji. (2017). Gambaran Terjadinya Pernikahan Dini Akibat Pergaulan Bebas. Jurnal Riset Kesehatan. Vol 5 No 1.
Nadhirah, Siti. (2017). Peranan Pendidikan Dalam Menghindari Pergaulan Bebas Anak Usia Remaja. Jurnal MUSAWA. Vol 9 No 2. 